\title{
Effect of a bed covering system in children with asthma and house dust mite hypersensitivity
}

\author{
J.M. Frederick*, J.O. Warner*, W.J. Jessop*, I. Enander**, J.A. Warner*
}

\begin{abstract}
Effect of a bed covering system in children with asthma and house dust mite hypersensitivity. J.M. Frederick, J.O. Warner, W.J. Jessop, I. Enander, J.A. Warner. CERS Journals Ltd 1997.

ABSTRACT: Allergen avoidance is regarded as an important approach to management of atopic asthma. The effect of Intervent bed covering systems on house dust mite (HDM) allergen exposure, asthma symptoms and markers of inflammation was investigated in 31 HDM sensitive asthmatic children.

Dust concentrations of Dermatophagoides pteronyssinus allergen 1 (Der $p$ 1) were monitored before and after covering the mattress, duvet and pillow with active and placebo covers for 3 months, in a single-blind, cross-over trial. Twice daily peak expiratory flow rate (PEFR), daily symptom scores and treatment schedule were recorded. Bronchial hyperresponsiveness was monitored by histamine challenge (provocative concentration of histamine causing a $20 \%$ fall in forced expiratory volume in one second (PC20)), and inflammation by measuring eosinophil cationic protein (ECP), eosinophil protein X (EPX), eosinophil peroxidase (EPO), and soluble interleukin-2 receptor (sIL-2R) in serum.

There was a significant reduction in $\operatorname{Der} p 1$ when the mattress, duvet and pillow were covered with the active bedding. There was no significant improvement in symptoms of asthma, PEFR, bronchodilator usage or PC20. Also, ECP, EPX, SIL-2R concentrations did not change for either treatment. EPO concentrations were significantly lower in the active compared to the placebo period.

The active bed covers reduced retrievable Dermatophagoides pteronyssinus allergen 1 (Der $p$ 1) from the bedding, with short term clinical benefit. Eur Respir J 1997; 10: 361-366.
\end{abstract}

*Child Health, University of Southampton, Southampton, UK. **Pharmacia AB, Uppsala, Sweden.

Correspondence: J.M. Frederick

Child Health

Level G, Centre Block

Southampton General Hospital

Tremona Road

Southampton

SO16 6YD

UK

Keywords: Asthma

barrier bed covers

children

eosinophil proteins

house dust mite

Received: October 301995

Accepted after revision October 121996
Asthma is the commonest chronic disease of childhood, and has increased in prevalence and severity in recent years $[1,2]$. House dust mites (HDMs) are known to be a major source of allergens, affecting $50-75 \%$ of atopic asthmatic individuals [3, 4]. Mattresses support large numbers of mites and their faeces (which contain the major allergen Dermatophagoides pteronyssinus allergen $1(\operatorname{Der} p$ 1) [5]. The particles are small $(10-40 \mu \mathrm{m})$ and movement in the bed can generate airborne allergen from the reservoir in the bedding.

It has been demonstrated that avoidance of allergen, e.g. at high altitude where allergen levels are low [6], and in the domestic environment [7], can be beneficial in the management of asthma.

Studies to evaluate various types of bedding covers have demonstrated potential benefits [7-11]. Initial studies used impermeable plastic covers [7-9], and a more recent study used polyurethane coated covers, but these covers are rather uncomfortable [10]. A clinical trial in children demonstrated a significant reduction in miteallergen exposure and subsequent reduction in bronchohyperresponsiveness (BHR) [11]. Further studies are required to establish the clinical contribution of bed coverings to the treatment of asthma [12].

A fabric called "Intervent" (W.L. Gore Associates,
Livingstone, UK), which is water vapour permeable (pore size $0.1 \mu \mathrm{m}$ ) but HDM allergen impermeable, has now been developed. Preliminary studies in adults with allergic rhinitis and asthma produced a significant clinical improvement [13]. A pilot study with Intervent covers established the need to cover the mattress, duvet and pillow to reduce exposure to $\operatorname{Der} p 1$ [14]. Recently, markers of eosinophil activation in serum and urine have been used as clinical assessments of asthma [15, 16]. In childhood asthma, raised serum levels of eosinophilic cationic protein (ECP) decreased with treatment [17, 18]. Also, serum ECP and eosinophil protein X (EPX) concentrations in asthmatic children changed significantly in association with exposure to, and avoidance of, allergens [19]. Additionally, elevated serum soluble interleukin-2 receptor (sIL-2R) (T-cell marker) concentrations have been demonstrated in asthma, which decrease with treatment [20].

This study investigated the effectiveness of Intervent bed covers in reducing Der $p 1$ exposure of HDM sensitive asthmatic children, with clinical symptoms monitored by lung function testing, peak flow measurements and diary cards, and disease activity by serum ECP, EPX, eosinophil peroxidase (EPO) and sIL-2R concentrations. 


\section{Materials and methods}

\section{Subjects}

Thirty one atopic asthmatic children (11 females and 20 males) aged 5-15 (mean 9) yrs were recruited from the Southampton General Hospital Paediatric asthma clinic from November 1992 to July 1993, i.e. 8 months. Informed consent was obtained from the legal guardians of all patients, and the study was approved by the Southampton University Hospitals Joint Ethics Committee. All patients had either a positive skin-prick test to HDM ( $\geq 4 \mathrm{~mm}$ in diameter) and/or specific immunoglobulin E (IgE) to HDM (radioallergenosorbent test (RAST) $\geq$ grade 3 ), and a documented history of perennial asthma. Pharmacotherapy was administered following the step-up schedule as outlined in the Paediatric Asthma Consensus Group publication [21]. Twenty nine patients had required prophylactic treatment (3 with sodium cromoglycate and 26 with inhaled steroids) as well as bronchodilator therapy, while two patients used bronchodilator alone (one male aged 5 yrs and one female aged 13 yrs). The duration of the study was 1 year (November 1992 until November 1993). The median forced expiratory volume in one second (FEV1) as a percentage of predicted for height was $78 \%$, with 16 of the 31 children having a FEV $1<80 \%$ pred.

\section{Bed covers}

Zippered Intervent covers (W.L. Gore, Livingstone, UK) or placebo polycotton covers for the mattress, duvet and pillow were used according to the protocol.

\section{Protocol}

This was a single-blind, cross-over study. After a 2 week run-in period, the 31 patients were randomly assigned to two groups (in order of recruitment). Group 1 (16 patients) received active bed covers, and Group 2 (15 patients) received placebo bed covers. These remained in situ for 3 months (Period 1), during which time they were asked to wipe down the active covers with a damp cloth, once a week (to remove settled dust). The covers were then removed and there was a wash-out period of 1 month.

Group 1 then received placebo covers and Group 2 active covers, for a further 3 months (Period 2).

\section{Dust sampling}

Dust samples were collected at Baseline 1, at the end of Period 1, end of wash-out period (Baseline 2), and at the end of Period 2.

These samples were taken from the whole area of the mattress $(3 \mathrm{~min})$, duvet $(5 \mathrm{~min})$ and pillow $(5 \mathrm{~min})$ using a Hoover dustette vacuum cleaner, adapted so that individual dust samples could be obtained using a standard collecting device (ALK, Denmark).

\section{Dust Der p 1 analysis}

For antigen determination, dust samples were extracted in phosphate-buffered saline (PBS) containing $0.5 \%$
Tween 20 and $0.2 \%$ bovine serum albumin (BSA) overnight (1:5 weight/volume). Samples were filtered (Anotop 10 plus, $0.2 \mu$; Whatman, Maidstone, UK) and analysed by means of an enzyme-linked immunosorbent assay (ELISA) system for $\operatorname{Der} p 1$, performed according to the manufacturers' recommendations (ALK Laboratories, Denmark).

\section{Diary cards}

Patients recorded symptom scores, medication, and peak expiratory flow rate (PEFR) as measured with a mini-Wright peak flow meter. PEFR was recorded before breakfast and bedtime medicines, the best of three blows being measured on each occasion. Symptoms were scored as follows: asthma last night (ALN) (0-3), daytime wheeze (DW) (0-3); and exercise tolerance (ET) (0-3). Consumption of inhaled bronchodilators, corticosteroids, sodium cromoglycate, and other medications was also recorded. Diary cards were completed for a run in period of 2 weeks, and throughout the trial. Average morning and evening PEFRs were calculated, and an average daily score for symptoms and bronchodilator use (over the last 2 weeks of each study period).

\section{Lung function}

Lung function tests were performed at Baseline 1 and at the end of Periods 1 and 2, using a Vitalograph compact spirometer (Buckingham, UK). When the patients had optimised their technique, the best of three flow-volume loops was taken for the calculation of baseline FEV1 as a percentage of predicted for age, height, and sex matched controls. The tests were performed after withholding all $\beta_{2}$-agonist medication for $12 \mathrm{~h}$. Reference values for lung function tests were taken from the data of POLGAR and Promadhat [22]. Patients then performed an inhalation provocation test with histamine acid phosphate using a standard modification of Cockroft's method [23]. A 2 min tidal volume breathing technique was used for inhalation, followed by spirometry at $0.5,1.5$ and $3 \mathrm{~min}$. Calibrated Intersurgical Cirrus nebulizers (Berkshire, UK) were used, filled with $4 \mathrm{~mL}$ histamine solution in doubling dilutions. Provocation concentrations for a 20\% drop in FEV1 (PC20) were calculated and log transformed.

\section{Blood assays}

Blood samples were drawn at Baseline 1 and at the end of Periods 1 and 2 using a 21-gauge butterfly needle with syringe attached, taking care to avoid haemolysis (thus potentially damaging the eosinophils). These were then transferred (needle removed) to unstoppered SST Vacutainer tubes with clot activator. They were allowed to stand for $60 \mathrm{~min}$ and then centrifuged at $3,500 \mathrm{rpm}$ for $10 \mathrm{~min}$. Serum was removed and aliquots stored at $-80^{\circ} \mathrm{C}$ until analysis.

ECP was measured by a fluorescent enzyme immunoassay (FEIA) using the Pharmacia CAP ${ }^{\mathrm{TM}}$ system (Pharmacia AB Diagnostics, Uppsala, Sweden). EPX was measured using a Pharmacia Radioimmunoassay (RIA). EPO was measured by I. Enander at Pharmacia, using a prototype FEIA on the CAP ${ }^{\mathrm{TM}}$ system. sIL-2R was measured by ELISA (T-cell Diagnostics, Cambridge, USA). 


\section{Statistical analysis}

The Mann Whitney U test was performed on the period differences between Groups 1 and 2 to determine the equality of the active and placebo bed covers. The Kruskal-Wallis test was performed on the diary card data on the difference between the baseline and the fol-

Table 1. - Skin-prick test results to common allergens in 30 patients (positive $\geq 4 \mathrm{~mm}$ wheal)

\begin{tabular}{lrlr}
\hline Allergen & $\begin{array}{r}\text { Pts } \\
\mathrm{n}\end{array}$ & Allergen & $\begin{array}{r}\text { Pts } \\
\mathrm{n}\end{array}$ \\
\hline HDM & 30 & Tree & 2 \\
Feathers & 7 & Alternaria & 1 \\
Cat & 19 & Cladosporium & 2 \\
Dog & 9 & Egg & 1 \\
Horse & 4 & Peanut & 2 \\
Grass & 16 & &
\end{tabular}

Pts: patients; HDM: house dust mite. lowing months. Statistical significance was achieved when p-value was equal to or less than 0.05 (95\% confidence interval $(95 \mathrm{CI} \%)$ ).

\section{Results}

Patients skin-prick test results to common allergens are recorded in table 1. Only one patient was monosensitive to HDM. Fifty percent of the patients were sensitive to pollens. Of these patients, $50 \%$ were exposed to a pollen season during the active period (but not in the last month alone), and 50\% during the placebo period of the study. Many of the children were sensitive to animals, and 7 of the 31 patients were exposed to a pet they were sensitized to during the whole study period.

Three patients were taking regular sodium cromoglycate ( 2 males and 1 female, aged 5-6 yrs), 26 inhaled corticosteroids (18 males and 8 females, aged 5-15 yrs) and two were using bronchodilators only (1 male aged $5 \mathrm{yrs}$ and one female aged $13 \mathrm{yrs}$ ).

Table 2. - Weight of dust ( $\mathrm{g}$ or $\mathrm{g} \cdot \mathrm{m}^{-2}$ area sampled) and concentration of Der $p 1$ allergen $\left(\mathrm{ng} \cdot \mathrm{g}^{-1} \mathrm{or} \mathrm{ng} \cdot \mathrm{m}^{-2} \mathrm{area}\right.$ sampled) in dust retrieved from bedding (at baseline and end of washout period), with active or placebo covers (in situ), for both arms of the study: Group 1 = Active $\rightarrow$ Placebo; Group 2 = Placebo $\rightarrow$ Active

\begin{tabular}{|c|c|c|c|c|c|c|c|}
\hline \multirow[t]{2}{*}{$\mathrm{Gp}$} & \multirow[t]{2}{*}{ Dust } & \multicolumn{3}{|c|}{ Baseline 1} & \multicolumn{3}{|c|}{$\begin{array}{l}\text { Period } 1 \\
\text { Active }\end{array}$} \\
\hline & & Mattress & Duvet & Pillow & Mattress & Duvet & Pillow \\
\hline 1 & $\begin{array}{l}\text { Weight } \\
\mathrm{g} \\
\text { Weight } \\
\mathrm{g} \cdot \mathrm{m}^{-2} \\
\operatorname{Der} p 1 \\
\mathrm{ng} \cdot \mathrm{g}^{-1} \\
\operatorname{Der} p 1 \\
\mathrm{ng} \cdot \mathrm{m}^{-2}\end{array}$ & $\begin{array}{c}0.175 \\
(0.051-0.791) \\
0.102 \\
(0.032-0.463) \\
12403 \\
(616-24138) \\
863 \\
(64-7891)\end{array}$ & $\begin{array}{c}0.111 \\
(0.014-0.449) \\
0.04 \\
(0.004-0.166) \\
20639 \\
(558-110000) \\
505 \\
(22-9696)\end{array}$ & $\begin{array}{c}0.084 \\
(0.013-0.408) \\
0.127 \\
(0.014-0.648) \\
10855 \\
(878-32500) \\
1364 \\
(137-11657)\end{array}$ & $\begin{array}{c}0.049 \\
(0.003-0.187) \\
0.029 \\
(0.002-0.131) \\
1246 \\
(0-66667) \\
50 \\
(0-3625)\end{array}$ & $\begin{array}{c}0.02 \\
(0-0.06) \\
0.006 \\
(0-0.022) \\
0 \\
(0-62500) \\
0 \\
(0-3719) \\
\text { Placebo }\end{array}$ & $\begin{array}{c}0.021 \\
(0-0.038) \\
0.029 \\
(0-0.06) \\
0 \\
(0-27727) \\
0 \\
(0-645)\end{array}$ \\
\hline \multirow[t]{2}{*}{2} & $\begin{array}{l}\text { Weight } \\
\mathrm{g} \\
\text { Weight } \\
\mathrm{g} \cdot \mathrm{m}^{-2} \\
\operatorname{Der} p 1 \\
\mathrm{ng} \cdot \mathrm{g}^{-1} \\
\operatorname{Der} p 1 \\
\mathrm{ng} \cdot \mathrm{m}^{-2}\end{array}$ & $\begin{array}{c}0.193 \\
(0.026-1.177) \\
0.116 \\
(0.015-0.83) \\
14759 \\
(0-82500) \\
1617 \\
(5-42263)\end{array}$ & $\begin{array}{c}0.088 \\
(0.014-0.393) \\
0.031 \\
(0.005-0.146) \\
23418 \\
(1095-67500) \\
525 \\
(33-9825)\end{array}$ & $\begin{array}{c}0.063 \\
(0.006-0.145) \\
0.103 \\
(0.01-0.23) \\
27586 \\
(398-1283333) \\
2582 \\
(65-12222)\end{array}$ & $\begin{array}{c}0.131 \\
(0.015-0.59) \\
0.077 \\
(0.011-0.414) \\
13500 \\
(900-63830) \\
1287 \\
(33-6316)\end{array}$ & $\begin{array}{c}0.081 \\
(0.034-0.179) \\
0.03 \\
(0.009-0.067) \\
6879 \\
(559-77419) \\
204 \\
(5-13333)\end{array}$ & $\begin{array}{c}0.06 \\
(0.02-0.128) \\
0.121 \\
(0.032-0.324) \\
5167 \\
(0-63158) \\
794 \\
(0-11111)\end{array}$ \\
\hline & & \multicolumn{3}{|c|}{ Baseline 2 (wash-out) } & & $\begin{array}{l}\text { Period } 2 \\
\text { Placebo }\end{array}$ & \\
\hline 1 & $\begin{array}{l}\text { Weight } \\
\mathrm{g} \\
\mathrm{Weight} \\
\mathrm{g} \cdot \mathrm{m}^{-2} \\
\operatorname{Der} p 1 \\
\mathrm{ng} \cdot \mathrm{g}^{-1} \\
\operatorname{Der} p 1 \\
\mathrm{ng} \cdot \mathrm{m}^{-2}\end{array}$ & $\begin{array}{c}0.248 \\
(0.053-0.692) \\
0.161 \\
(0.031-0.403) \\
7275 \\
(100-30519) \\
1095 \\
(12-3177)\end{array}$ & $\begin{array}{c}0.126 \\
(0.065-0.276) \\
0.044 \\
(0.024-0.102) \\
5715 \\
(461-25325) \\
248 \\
(11-722)\end{array}$ & $\begin{array}{c}0.087 \\
(0.017-0.221) \\
0.127 \\
(0.027-0.289) \\
7250 \\
(288-70588) \\
1000 \\
(54-11746)\end{array}$ & $\begin{array}{c}0.145 \\
(0.07-0.667) \\
0.102 \\
(0.041-0.39) \\
2737 \\
(53-97143) \\
190 \\
(8-3977)\end{array}$ & $\begin{array}{c}0.106 \\
(0.047-0.185) \\
0.038 \\
(0.017-0.069) \\
4135 \\
(468-21667) \\
127 \\
(19-722) \\
\text { Active }\end{array}$ & $\begin{array}{c}0.054 \\
(0.009-0.272) \\
0.092 \\
(0.014-0.288) \\
7779 \\
(707-93333) \\
563 \\
(46-4505)\end{array}$ \\
\hline 2 & $\begin{array}{l}\text { Weight } \\
\mathrm{g} \\
\text { Weight } \\
\mathrm{g} \cdot \mathrm{m}^{-2} \\
\operatorname{Der} p 1 \\
\mathrm{ng} \cdot \mathrm{g}^{-1} \\
\operatorname{Der} p 1 \\
\mathrm{ng} \cdot \mathrm{m}^{-2}\end{array}$ & $\begin{array}{c}0.38 \\
(0.05-0.655) \\
0.235 \\
(0.035-0.460) \\
8500 \\
(354-50000) \\
1058 \\
(17-17824)\end{array}$ & $\begin{array}{c}0.113 \\
(0.056-0.293) \\
0.04 \\
(0.021-0.109) \\
10429 \\
(277-29737) \\
425 \\
(7-2654)\end{array}$ & $\begin{array}{c}0.092 \\
(0.034-0.177) \\
0.158 \\
(0.054-0.327) \\
19210 \\
(46-621747) \\
2143 \\
(12-17460)\end{array}$ & $\begin{array}{c}0.047 \\
(0-0.097) \\
0.026 \\
(0-0.057) \\
1086 \\
(0-6452) \\
35 \\
(0-234)\end{array}$ & $\begin{array}{c}0.017 \\
(0-0.063) \\
0.006 \\
(0-0.023) \\
0 \\
(0-2231) \\
0 \\
(0-21)\end{array}$ & $\begin{array}{c}0.015 \\
(0-0.058) \\
0.024 \\
(0-0.105) \\
0 \\
(0-3333) \\
0 \\
(0-79)\end{array}$ \\
\hline
\end{tabular}

Values are expressed as median, and range in parenthesis. Der $p$ 1: Dermatophagoides pteronyssinus allergen 1; Gp: group. 


\section{Der $\mathrm{p} 1$ concentrations}

The weight of dust $(\mathrm{g})$, or $\mathrm{g} \cdot \mathrm{m}^{-2}$ area sampled, and concentration of Der $p 1\left(\mathrm{ng} \cdot \mathrm{g}^{-1}\right)$ and $\left(\mathrm{ng} \cdot \mathrm{m}^{-2}\right.$ area sampled) for Groups 1 and 2 are summarized (median and range) in table 2. There was a significant decrease in the concentration of Der $p 1\left(\mathrm{ng} \cdot \mathrm{g}^{-1}\right)$ in the recoverable dust from the mattress $(\mathrm{p}=0.0012)$, duvet $(\mathrm{p}<0.0001)$ and pillow $(\mathrm{p}<0.0001)$ after the addition of active bed covers compared to placebo covers (fig. 1); and also, if expressed as $n g \cdot \mathrm{m}^{-2}(\mathrm{p} \leq 0.0001$ for mattress, duvet and pillow).

\section{Diary card analysis}

Diary card analysis indicated that the baselines for the active and placebo periods were significantly different, and so all subsequent data had to be compared

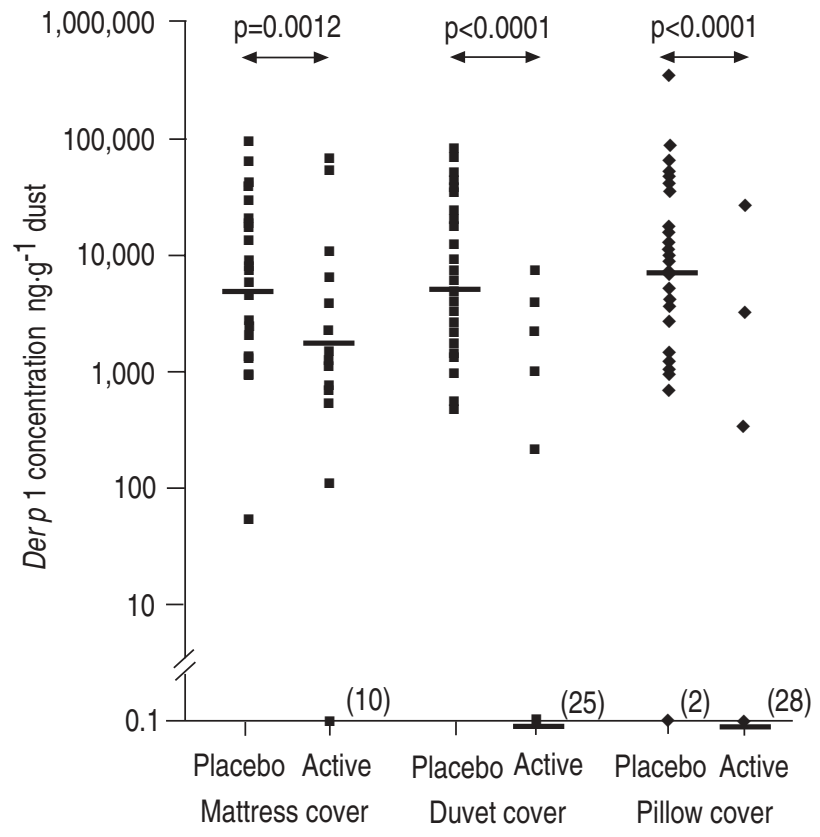

Fig. 1. - Dermatophagoides pteronyssinus allergen 1 (Der $p$ 1) concentrations (ng. $\left.\mathrm{g}^{-1}\right)$ in the mattress, duvet and pillow after 3 months with active and placebo bed covers in situ. Median values are shown by horizontal bars. Values in parentheses represent the number samples with undetectable levels of Der $p 1$. to their own baseline (table 3 ). There was no significant improvement in symptoms of asthma during the active and placebo periods of the study, although from the figures, there is a suggestion of an improvement in symptoms of daytime wheeze and exercise tolerance during the first two months with active covers in situ. There was no significant improvement in symptoms during the placebo period of the study. There was no significant change in PEFR or bronchodilator usage between the two periods. There was, however, a trend for evening PEFR to improve in the active group ( $\mathrm{p}=$ 0.09) after the first two months of the study. Similarly the morning PEFR showed a trend to improve in the placebo group after three months $(\mathrm{p}=0.08)$.

\section{Lung function}

The range of PEFR at baseline was $55-113 \%$ pred (median $84 \%$ pred). The range of FEV1 at baseline was $43-105 \%$ predicted (median $78 \%$ ). There was no significant difference in FEV1 $(\mathrm{p}=0.6)$ after the active bed covers (median $85 \%$ pred, range $53-114 \%$ pred) compared to their baseline (median $86 \%$ pred, range $43-123 \%$ pred). Also, PC20 histamine showed no significant difference $(\mathrm{p}=0.15)$ between the active (median $0.3 \mathrm{mg} \cdot \mathrm{mL}^{-1}$, range $0.05-2.1 \mathrm{mg} \cdot \mathrm{mL}^{-1}$ ) and placebo (median $0.4 \mathrm{mg} \cdot \mathrm{mL}^{-1}$, range $\left.0.05-2.6 \mathrm{mg} \cdot \mathrm{mL}^{-1}\right)$ treatments.

\section{Blood samples}

Blood samples were obtained from 30 of the 31 patients on all three occasions. One patient consistently refused blood sampling (a female aged 6 yrs).

Currently, there are few published data on paediatric ranges for the eosinophil proteins [24], and the present results have been compared to normal healthy adults values. The range of ECP in these patients at baseline was $<2-43.3 \mu \mathrm{g} \cdot \mathrm{L}^{-1}$ (mean $13.4 \mu \mathrm{g} \cdot \mathrm{mL}^{-1}$ ), with nine patients above the upper limit for adults. The range of EPX in these patients at baseline was $14-171 \mu \mathrm{g} \cdot \mathrm{L}^{-1}$ (mean $\left.53.8 \mu \mathrm{g} \cdot \mathrm{mL}^{-1}\right)$, with 20 patients above the upper limit for adults. The range of EPO in these patients at baseline was $0.8-146 \mu \mathrm{g} \cdot \mathrm{L}^{-1}$ (mean $34.3 \mu \mathrm{g} \cdot \mathrm{L}^{-1}$ ), with 22 patients above the upper limit for adults. At baseline, there was no significant difference in the EPO levels in

Table 3. - Daily average (last 2 weeks of each month) of symptom scores (0-3) and daily medication ( $\mu \mathrm{g} \beta_{2}$-agonist), from diary cards for each of the 3 months using active and placebo bed covers compared to the baseline

\begin{tabular}{|c|c|c|c|c|c|c|c|c|c|}
\hline \multirow{2}{*}{\multicolumn{2}{|c|}{ Diary }} & \multirow[t]{2}{*}{ Baseline } & \multicolumn{3}{|c|}{ Active } & \multirow[t]{2}{*}{ Baseline } & \multicolumn{3}{|c|}{ Placebo } \\
\hline & & & Month 1 & Month 2 & Month 3 & & Month 1 & Month 2 & Month 3 \\
\hline ALN score & & $\begin{array}{c}0.2 \\
(0-1.9)\end{array}$ & $\begin{array}{c}0.1 \\
(0-0.9)\end{array}$ & $\begin{array}{c}0.07 \\
(0-0.8)\end{array}$ & $\begin{array}{c}0.1 \\
(0-0.8)\end{array}$ & $\begin{array}{c}0.09 \\
(0-2.5)\end{array}$ & $\begin{array}{c}0.1 \\
(0-2.4)\end{array}$ & $\begin{array}{c}0.03 \\
(0-1.7)\end{array}$ & $\begin{array}{c}0.09 \\
(0-1.7)\end{array}$ \\
\hline DW score & & $\begin{array}{c}0.4 \\
(0-1.2)\end{array}$ & $\begin{array}{c}0.3 \\
(0-1.1)\end{array}$ & $\begin{array}{c}0.3 \\
(0-1.1)\end{array}$ & $\begin{array}{c}0.3 \\
(0-1.1)\end{array}$ & $\begin{array}{c}0.3 \\
(0-2.1)\end{array}$ & $\begin{array}{c}0.2 \\
(0-2.2)\end{array}$ & $\begin{array}{c}0.1 \\
(0-1.6)\end{array}$ & $\begin{array}{c}0.2 \\
(0-1.1)\end{array}$ \\
\hline ET score & & $\begin{array}{c}0.4 \\
(0-1.6)\end{array}$ & $\begin{array}{c}0.2 \\
(0-1.1)\end{array}$ & $\begin{array}{c}0.2 \\
(0-1.1)\end{array}$ & $\begin{array}{c}0.2 \\
(0-1.1)\end{array}$ & $\begin{array}{c}0.2 \\
(0-2.1)\end{array}$ & $\begin{array}{c}0.2 \\
(0-2.2)\end{array}$ & $\begin{array}{c}0.1 \\
(0-1.6)\end{array}$ & $\begin{array}{c}0.2 \\
(0-1.2)\end{array}$ \\
\hline PEFR a.m. & $\mathrm{L} \cdot \mathrm{min}^{-1}$ & $\begin{array}{c}262 \\
(132-389)\end{array}$ & $\begin{array}{c}255 \\
(137-407)\end{array}$ & $\begin{array}{c}263 \\
(155-379)\end{array}$ & $\begin{array}{c}257 \\
(177-391)\end{array}$ & $\begin{array}{c}269 \\
(141-390)\end{array}$ & $\begin{array}{c}264 \\
(154-432)\end{array}$ & $\begin{array}{c}272 \\
(158-431)\end{array}$ & $\begin{array}{c}282 \\
(155-428)\end{array}$ \\
\hline PEFR p.m. & $\mathrm{L} \cdot \mathrm{min}^{-1}$ & $\begin{array}{c}265 \\
(142-402)\end{array}$ & $\begin{array}{c}277 \\
(141-416)\end{array}$ & $\begin{array}{c}290 \\
(147-396)\end{array}$ & $\begin{array}{c}258 \\
(174-407)\end{array}$ & $\begin{array}{c}274 \\
(160-418)\end{array}$ & $\begin{array}{c}283 \\
(159-431)\end{array}$ & $\begin{array}{c}301 \\
(164-428)\end{array}$ & $\begin{array}{c}307 \\
(167-432)\end{array}$ \\
\hline Medication & $\mu \mathrm{g}$ & $\begin{array}{c}120 \\
(0-986)\end{array}$ & $\begin{array}{c}60 \\
(0-816)\end{array}$ & $\begin{array}{c}80 \\
(0-634)\end{array}$ & $\begin{array}{c}80 \\
(0-312)\end{array}$ & $\begin{array}{c}60 \\
(0-542)\end{array}$ & $\begin{array}{c}60 \\
(0-816)\end{array}$ & $\begin{array}{c}20 \\
(0-490)\end{array}$ & $\begin{array}{c}40 \\
(0-372)\end{array}$ \\
\hline
\end{tabular}

Values are median, and range in parenthesis. ALN: asthma last night; DW: daytime wheeze; ET: exercise tolerance; PEFR: peak expiratory flow rate. 


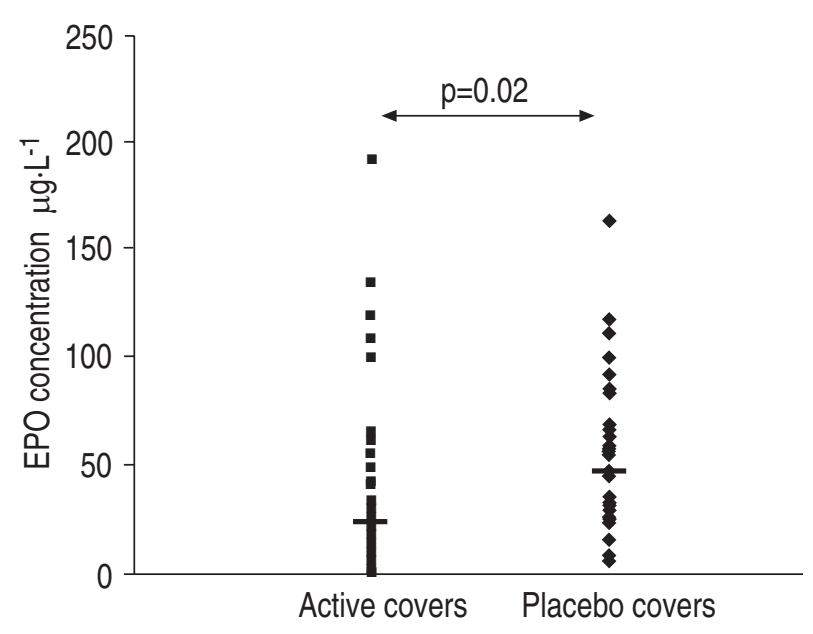

Fig. 2. - Serum eosinophil peroxidase (EPO) concentration $\left(\mu \mathrm{g} \cdot \mathrm{L}^{-1}\right)$ after 3 months with active or placebo bed covers. Horizontal bars show median values.

those patients going into Group 1 (range $0.8-72 \mu \mathrm{g} \cdot \mathrm{L}^{-1}$, mean $26.1 \mu \mathrm{g} \cdot \mathrm{L}^{-1}$ ) or Group 2 (range $0.9-146 \mu \mathrm{g} \cdot \mathrm{L}^{-1}$, mean $\left.43.7 \mu \mathrm{g} \cdot \mathrm{L}^{-1}\right)$.

There were significantly lower levels of EPO $(p=0.02)$ after the active bed covers had been in situ compared to the placebo bed covers (fig. 2). Although there seemed to be some trend for the levels of ECP and EPX to be lower after active bed covers compared to placebo covers, this was not significant ( $\mathrm{p}=0.16$ and $\mathrm{p}=0.19$, respectively). The range of sIL-2R in these patients at baseline was 189-907 U. $\mathrm{mL}^{-1}$ (median $600 \mathrm{U} \cdot \mathrm{mL}^{-1}$ ) i.e. none were above the upper level for healthy children in this age range [25]. There was no difference $(p=0.33)$ in sIL-2R after the addition of active compared to placebo covers.

\section{Discussion}

Most previous studies of allergen avoidance involving barrier bed covers have looked at mattress dust alone and have not considered the contribution of the dust reservoirs present in other items of bedding. These undoubtedly add to the allergen pool in the bedroom environment. Our previous study showed that, due to high Der $p 1$ concentrations in the various items of bedding, covering the mattress alone is not sufficient to significantly reduce Der $p 1$ exposure [14].

Although the first International Workshop on dust mite allergy [26] suggested that $10 \mu \mathrm{g} \cdot \mathrm{g}^{-1}$ is a risk factor for acute asthma in mite allergic people, $87 \%$ of our patients had concentrations greater than this in at least one item of their bedding, and they were not all suffering from acute asthma. This suggests either that they were well-controlled by medication or that the threshold is inappropriate for the UK. The third International Workshop (Cuenca, Spain 1995) decided that the relationship between exposure and symptoms of asthma among sensitized individuals is very complex, and a simple threshold for symptoms is inappropriate (PlattsMills TAE, personal communication). The Intervent bed covers significantly reduced both the concentration of allergen and amount of dust retrieved from the bedding compared to the placebo covers. However, with the placebo covers, there was a significant reduction in the Der p 1 concentration $\left(\mathrm{ng} \cdot \mathrm{m}^{-2}\right)$ retrieved from the pillow, with a tendency to decrease in the mattress also. This did not, however, result in significant clinical benefit, but there was a trend for improvement in morning PEFR by the end of 3 months with placebo covers. This suggests that even the placebo had a beneficial effect in preventing release of allergen into the air.

There was some indication that an improvement in some symptoms of asthma may have been achieved with the active bed covers over the first two months of the study, but these were of minor magnitude and there was a large range in the data. A larger study would be required to investigate this further. These results imply that the effectiveness of the measure, if any, is short-lived. Clearly, there are many other sources of allergen which may confound the results. However, as a single intervention the results are promising, and the incorporation of Intervent bed covers into a multisystem avoidance programme may provide more successful results. We also hypothesize that the allergen levels may actually increase in the carpet around the bed whilst using the active bed covers, as skin scales will accumulate on the surface of the cover (that would normally have gone into the mattress) and be swept onto the floor. More frequent damp wiping of the covers may be required. This could account for the loss of effect after 2 months. Unfortunately, we did not collect dust samples from the carpet and this would be advisable in future studies on bed covers.

Many factors will mitigate against a single allergen avoidance intervention achieving significant benefits, and a number were operative in the present study. Fifty percent of the patients were sensitized to pollens, though the exposure was comparable between the groups, and $25 \%$ of the patients were exposed constantly to an animal to which they were sensitized. Undoubtedly, viral infections will also have played a role in aggravating asthma and we could not assess their contribution to the outcome, as this is only possible with very expensive technology.

The histamine challenge test did not demonstrate an improvement in the active group but its value as a monitor of clinical change has come under much scrutiny recently [27]. Little change, however, was observed in twice daily PEFR. As all patients were reasonably controlled on regular prophylactic therapy, it was probably unreasonable to expect much change in these parameters.

The serum eosinophil proteins declined after the addition of active bed covers, with the fall in EPO being significant. There is selective release of different proteins from eosinophils, and TomAssini et al. [28] have demonstrated EPO release after IgE stimulation, whereas ECP release was demonstrated with anti-immunoglobulin $\mathrm{G}$ ( $\mathrm{IgG})$ monoclonal stimulation. CARLSON et al. [29] have also shown a significant rise in ECP and EPX in pollen-atopic patients with asthma during the pollen season. There is, however, a more rapid and 10 fold more significant rise in EPO in this group [30]. sIL-2R showed no change after either type of bed covers. However, as none of the patients in this study had elevated levels on recruitment, this is perhaps not surprising. We have shown that this T-cell marker decreases, only very slowly, with long-term allergen avoidance at high altitude [31]. 
Overall, we believe that this study has demonstrated that there is a decrease in serum eosinophil peroxidase amongst a group of well controlled asthmatics using Intervent bed covers, coincident with a decrease in recoverable Dermatophagoides pteronyssinus allergen 1 (Der $p$ 1) from the bedding. However, it is likely to be necessary to follow other house dust mite avoidance measures, such as the removal of carpets (particularly the deep pile type), improved ventilation and decreased humidity, in order to obtain a more persistent and greater effect. Barrier bed covers, however, offer one of the simplest and most effective approaches to reduction of house dust mite allergen exposure in asthmatic children, and should be considered the first approach to allergen avoidance.

Acknowledgements: We would like to thank W.L. Gore for funding JMF and WJJ and for providing the "Intervent" bedding covers for the study. They would also like to thank the National Asthma Campaign and the British Lung Foundation for funding JAW, and Pharmacia AB (Sweden) for providing assays kits for $\mathrm{ECP}, \mathrm{EPX}$, and for measuring EPO.

\section{References}

1. Burr ML. Changes in asthma prevalence: 2 surveys 15 years apart. Arch Dis Child 1989; 64: 1452-1456.

2. Jackson R, Sears MR, Beaglehole R, Rea H. International trends in asthma mortality: 1970-1985. Chest 1988; 94 : 914-918.

3. Sarsfield JK. Role of house dust mites in childhood asthma. Arch Dis Child 1974; 49: 711-715.

4. Maunsell K, Wraith DG, Cunningham AM. Mite and house dust biology in bronchial asthma. Lancet 1968; 1: $1267-1270$.

5. Van Bronswijk JEMH. In: House dust biology for allergists, acarologists and mycologists. The Netherlands, Zeist NIB Publishers, 1981.

6. Peroni DG, Boner AL, Valine G, Antolini I, Warner JO. Effective allergen avoidance at high altitude reduces allergen-induced bronchial hyperresponsiveness. Am J Respir Crit Care Med 1994; 149: 1442-1446.

7. Murray AB, Ferguson AC. Dust-free bedrooms in the treatment of asthmatic children with house dust or house dust mite allergy: a controlled trial. Pediatrics 1983; 71: 418-422.

8. Walshaw MJ, Evans CC. Allergen avoidance in house dust mite sensitive adult asthma. $O \mathrm{~J} \mathrm{Med} \mathrm{1986;58:}$ 199-215.

9. Sarsfield JK, Gowland G, Toy R, Norman ALE. Mite sensitive asthma of childhood: trial of avoidance measures. Arch Dis Child 1974; 49: 716-721

10. Owen S, Morganstern M, Hepworth J, Woodcock A. Control of house dust mite antigen in bedding. Lancet 1990; 335: 396-397.

11. Ehnert B, Lau-Schadendorf S, Weber A, Buettner B, Shou C, Wahn U. Reducing domestic exposure to dust mite allergen reduces bronchial hyperreactivity in sensitive children with asthma. J Allergy Clin Immunol 1992; 90: 135-138

12. Colloff MJ, Ayres J, Carswell F, et al. The control of allergens of dust mites and domestic pets: a position paper. J Clin Exp Allergy 1992; 22 (Suppl. 2): 1-28.

13. Howarth PH, Lunn A, Tomkins S. A double-blind, placebo-controlled trial of Intervent bedding system in perennial allergic rhinitis (abstract). J Allergy Clin Immunol 1992; 89: 305.

14. Hegarty JM, Jessop WJ, Warner JA, Warner JO. The effect of a bed covering system on airborne levels of house dust mite allergen. Allergy 1993; 48 (Suppl. 16): 108 (Abstract 2050).

15. Rao R, Warner JO. Airways inflammation: is it relevant to childhood asthma? Baillieres Clin Paediatrics 1995; 3: 277-296.

16. Gleich GJ, Adolphson CR. The eosinophil leucocyte: structure and function. Adv Immunol 1986; 39: 177-253.

17. Zimmerman BN, Enander I, Zimmerman R, Ahlstedt S. Asthma in children under 5 years of age: eosinophils and serum levels of eosinophil proteins ECP and EPX in relation to atopy and symptoms. Clin Exp Allergy 1994; 24: 149-155.

18. Kristjansson S, Strannegard I, Strannegard O, et al. Urinary eosinophil protein $\mathrm{X}$ in children with atopic asthma: a useful marker of anti-inflammatory treatment. J Allergy Clin Immunol 1996; 97: 1179-1187.

19. Boner AL, Peroni DG, Piacentini GL, Venge P. Influence of allergy avoidance at high altitude on serum markers of eosinophil activation in children with allergic asthma. Clin Exp Allergy 1993; 23: 1021-1026.

20. Lai CKW, Chan CHS, Leung JCK, Lai K. Serum concentration of soluble interleukin-2 receptors in asthma. Chest 1993; 103: 782-786.

21. Warner JO, Neijens HJ, Landau LI, et al. Asthma: a follow-up statement from an international paediatric asthma consensus group. Arch Dis Child 1992; 67: 240-248.

22. Polgar G, Promadhat U. In: Pulmonary function testing in children. Philadelpia, W.B. Saunders and Co., 1971.

23. Reiser J, Wadsworth J, Nunn A, Warner JO. Expression of results of histamine challenge. Pediatr Pulmonol 1989; 6: 242-245.

24. Zimmerman B, Lanner A, Enander I, Zimmerman RS, Peterson CGB, Ahlstedt S. Total blood eosinophils, serum eosinophil cationic protein and eosinophil protein $\mathrm{X}$ in childhood asthma: relation to disease status and therapy. Clin Exp Allergy 1993; 23: 564-570.

25. Jones AC, Besley CR, Warner JA, Warner JO. Variations in serum soluble IL-2 receptor concentration. Pediatr Allergy Immunol 1994; 5: 230-234.

26. International Workshop Report. Dust mite allergens and asthma: a worldwide problem. $J$ Allergy Clin Immunol 1989; 83: 416-427.

27. Kerstjens HAM, Brand PLP, de Jong PM, et al. Influence of treatment on peak expiratory flow and its relation to airway hyperresponsiveness and symptoms. Thorax 1994; 49: 1109-1115.

28. Tomassini M, Tsicopoulos A, Chun Tai P, et al. Release of granule proteins by eosinophils from allergic and nonallergic patients with eosinophilia on immunoglobulindependent activation. J Allergy Clin Immunol 1991; 88: 365-375.

29. Carlson M, Hakansson L, Kampe M, Stalenheim G, Peterson C, Venge P. Degranulation of eosinophils from pollen-atopic patients with asthma is increased during the pollen season. J Allergy Clin Immunol 1992; 89: 131-139.

30. Peterson C, Eklund E, Nilsson M, Carlson M, Enander I, Venge P. Immunoassay of human eosinophil peroxidase (EPO): levels of EPO in serum during pollen season in atopic asthmatics. Eur Respir J 1995; 8 (Suppl. 19): 228s (Absract P1167).

31. Warner JA, Peroni DG, Jones AJ, et al. Soluble IL-2R: a marker of effective allergen avoidance? (Abstract) Eur Respir J 1993; 6: 538. 